\title{
MIMOSA PUDICA EXERTS NEUROPROTECTION AGAINST MPP+INDUCED NEUROTOXICITY IN SHSY5Y CELL LINES-AN IN VITRO MODEL OF ANTI-PARKINSONISM
}

\author{
MAHADEVAN M. V. ${ }^{1}$, RAMASWAMY R...$^{2^{*}}$, BANUMATHI V. ${ }^{3}$ \\ ${ }^{1}$ Sirappu Maruthuvam Department, National Institute of Siddha, Chennai 600047, India, ${ }^{2}$ Director General, Central Council for Research in \\ Siddha, Ministry of AYUSH, Govt of India, Govt Anna Hospital campus, Arumbakkam, Chennai 600106, India, ${ }^{3}$ Director, National Institute \\ of Siddha, Chennai 600047, India \\ Email: dr.rsramaswamy@gmail.com
}

Received: 17 Oct 2016 Revised and Accepted: 11 Nov 2016

\begin{abstract}
Objective: Parkinson's disease (PD) is one of the of a neurodegenerative disorder, It's decreased the dopaminergic neurones, tyrosine hydroxylase (TH) and increased the $\alpha$-synuclein protein level. This study was conducted to investigate the neuroprotective effect of Mimosa pudica have the abilities to improve TH and DAT proteins expression against MPP+ induced neurotoxicity, in in vitro model of Parkinson's disease using SH-SY5Y human neuroblastoma cell lines.
\end{abstract}

Methods: Mimosa pudica were pre-treated with various concentration for cell viability assay. Vehicle alone or Mimosa pudica (300 $\mu$ g) for $24 \mathrm{~h}$, and then were co-treated with $1000 \mu \mathrm{M}$ MPP + for $15 \mathrm{~min}$ in the continued presence of vehicle or Mimosa pudica. After treatment, cells were collected for protein expression.

Results: Cell viability assay confers the inhibitory concentration cell death of Mimosa pudica. MPP+ significantly down-regulated the protein expression of TH $(\mathrm{p}<0.01)$ and DAT $(\mathrm{p}<0.05)$. Mimosa pudica decreased the expression of $\alpha$ synuclein $(\mathrm{p}<0.01)$ in MPP+ intoxicated cell lines.

Conclusion: The present study showed that Mimosa pudica exerts neuroprotection by suppressing $\alpha$ synuclein and the dopaminergic neurdegeneration. Mimosa pudica may be due to quecertin which might be acted via the anti-oxidant mechanism. The above finding suggests that Mimosa pudica may act as a potential target in the management of PD.

Keywords: Parkinson's disease, Mimosa pudica, Siddha medicine, SH-SY5Y, MPP+, $\alpha$ synuclein, Tyrosine hydroxylase, Dopamine Transporter

(c) 2017 The Authors. Published by Innovare Academic Sciences Pvt Ltd. This is an open access article under the CC BY license (http://creativecommons.org/licenses/by/4. 0/) DOI: http://dx.doi.org/10.22159/ijpps.2017v9i1.15728

\section{INTRODUCTION}

Siddha system of medicine, which is practised prevalently in the southern part of India, especially in Tamil Nadu, is familiar among Tamil-speaking people and outside of the landscape too. The name Siddha medicine owes its origin to medicinal ideas and practices rendered by sages called Siddhar's/"Holy immortals". Siddha system of medicine is established mainly with 18 Siddhas and the most renowned are Agathiyar, Thiru moolar and Bhogar [1].

Parkinson's disease (PD) is one of the of neurodegenerative disorders characterized by paucity and slowness of the movement (bradykinesia), tremor at rest, rigidity, shuffling gait and flexed posture. Decreased levels of dopaminergic neuronal density in the substantia nigra (SNpc) and striatum (ST) and more importantly tyrosine hydroxylase $(\mathrm{TH})$, the rate-limiting enzyme in dopamine synthesis, are major biochemical indications in PD pathology. Remarkable impeachment of $\alpha$-synuclein (SYN) provokes Lewy body (LB) pathologies that involve the deposition of LBs in cell bodies. Upregulation of SYN was shown to trigger the generation of TNF- $\alpha$ and IL-1 $\beta$ in cultured Neuronal cell lines [2, 3]

Commonly vaatha diseases mentioned in Siddha are correlated to neurological disorders in modern medicine parallel with Siddha system. In Siddha, the vaatha diseases (vitiated vaatha humour) like Paanikamba vatham, Sirathamba vatham and Nadukku Vaatham wherein the patients clinically express difficulty in walking, resting tremor and loss of sensation (chronic status) in hands and feet, rigidity, and sleeplessness reflects the features of Parkinson's disease [4]. These notions ascribe to the existence of medical knowledge and diagnostic procedures of PD were in Siddha even before the scientific demonstration of PD. The clinical correlation in both Siddha and modern medicine demonstrates the motor and cognitive dysfunctions in PD. In Siddha, treatment of PD is basically aimed at restoring vitiated vaatham by external and internal therapies. Major herbs and herbo-mineral preparations used includes Mucuna pruriens, Ulunthu thylum, (5) and Kalamega Narayana chendooram, [17] etc., which are shown to restore vitiated vaatham and thereby motor functions in PD [5]. In Siddha medicine, Mimosa pudica (Fam: Fabaceae) is indicated to treat diabetes mellitus, chronic wounds and impotency. Mimosa pudica possesses hypnotic action which shows its ability to penetrate the blood-brain barrier. Mimosa pudica relives "Odu vaatham" a kind of vaatha disease [6]. Based on the traditional clinical indication, the present study was performed to understand the neuroprotective activity of Mimosa pudica in in vitro model of PD using SHSY5Y human neuroblastoma cell lines. The study reveals that Mimosa pudica have the abilities to improve TH and DAT proteins expression against $\mathrm{MPP}+$ induced neurotoxicity, an in vitro model of PD.

\section{MATERIALS AND METHODS}

\section{Chemicals and reagents}

Entire plant raw powder of Mimosa pudica was procured from M/s. Arogya Health Care Pvt. Ltd Chennai (MUG/2725/16-17). SHSY5Y human neuroblastoma was procured from NCCS, pune, india. MPP+iodide, mouse anti-TH, mouse anti- $\alpha$ synuclein, rat anti-DAT, and anti-mouse IgG were purchased from Sigma-Aldrich, USA. Immuno Cruz mouse ABC Staining kit was procured from Santa Cruz, USA. All the other chemicals and reagents used were of analytical grade and were obtained from SISCO Research Laboratories Pvt Ltd. Mumbai, India.

\section{Standardisation of Mimosa pudica by HPTLC}

Mimosa pudica was subjected to basic phytochemical analysis and major secondary metabolites such as tannins, flavonoids, and total phenols content were estimated following standard protocols. Mimosa pudica was standardised for quercetin content in HPTLC using silica gel GF254 as the stationary phase and chloroform: ethyl acetate: formic Acid: $\mathrm{MeOH}$ (3: 3: 0.4:0.1) as mobile phase [18]. Spots were developed in ascending mode and scanned at $412 \mathrm{~nm}$. 
Mimosa pudica $(10 \mathrm{mg} / \mathrm{ml})$ and quercetin $(100 \mu \mathrm{g} / \mathrm{ml})$ were prepared in methanol.

\section{Cell culture maintenance and treatment}

Human neuroblastoma SH-SY5Y cells (NCCS, Pune), possess morphological, biochemical, and electrophysiological characteristics of dopaminergic neurones and have been widely used in the study of cell model for PD [7]. Cells were cultured in DMEM+F12 supplemented with $10 \%(\mathrm{v} / \mathrm{v})$ heat-inactivated foetal calf serum and 100 units/ml penicillin/streptomycin. Cells were kept at $37{ }^{\circ} \mathrm{C}$ in humidified $5 \% \mathrm{CO}_{2}$ and $95 \%$ air. All experiments were carried out 24-48 h after cells were seeded. The cells were pre-treated with vehicle alone or Mimosa pudica $(300 \mu \mathrm{g})$ for $24 \mathrm{~h}$, and then were cotreated with $1000 \mu \mathrm{M} \mathrm{MPP} \mathrm{MP}^{+}$for $15 \mathrm{~min}$ in the continued presence of vehicle or Mimosa pudica. A pilot experiment was carried out with various concentrations of Mimosa pudica using cell viability as the end point and $300 \mu \mathrm{g}$ Mimosa pudica provided the maximum reduction in cell death (data not shown) hence further studies were carried out using 100 and $300 \mu \mathrm{g}$ of Mimosa pudica.

\section{Cell viability or MTT assay}

SHSY5Y cells were seeded in 96-well plates at a density of 8,000 cells $/ 200 \mu \mathrm{l} /$ well for $24 \mathrm{~h}$. Cells were treated with Mimosa pudica (1$1000 \mu \mathrm{g} / \mathrm{ml}$ ), and incubated at $37^{\circ} \mathrm{C}$ for next $24 \mathrm{~h}$. At $20 \mathrm{~h}$ following mimosa treatment, cells were incubated with $5 \mathrm{mg} / \mathrm{ml}$ MTT for $4 \mathrm{~h}$. At the end of the experiment, the medium was removed, the insoluble formazan product was dissolved in DMSO $(100 \mu \mathrm{l})$ and kept in the dark for $15 \mathrm{~min}$. The intensity of purple colour developed was measured at 570 and $630 \mathrm{~nm}$. Inhibitory concentration 50 (IC50) of Mimosa pudica was calculated using the formula:

$\%$ Growth inhibitory rate $=([\text { Control OD-Test OD }] / \text { Control OD })^{* 100}$

\section{Western blot analysis}

SHSY5Y were seeded in 6 well poly-D-lysine precoated plates (25 $\mu \mathrm{g} / \mathrm{ml}$ ) at a density of $1 \mathrm{X} 10^{6}$ cells/well and allowed to grow for a period of $48 \mathrm{~h}$. Sterile filtered Mimosa pudica or vehicle will be added to the pre-fixed wells and incubated for $24 \mathrm{~h} .1000 \mu \mathrm{M} / \mathrm{ml}$ of MPP+ was added to respective wells and incubated for 15 min to induce neurotoxicity. Following incubation, all the wells will be refreshed with media and left overnight. Cells were lysed with $0.1 \mathrm{ml}$ lysis buffer (1\% NP40; 50 mmol Tris-HCl, pH 7.6; 5 mmol EDTA), followed by $30 \mathrm{~min}$ incubation on ice. The lysate was centrifuged at $15,000 \mathrm{~g}$ for $10 \mathrm{~min}$ at $4^{\circ} \mathrm{C}$. The supernatant portion (total lysate) was collected, and protein levels were determined. Samples containing $40 \mu \mathrm{g}$ protein were used to separate SDS-PAGE (100V) and transferred to PVDF membrane $(230 \mathrm{~mA}$ for $90 \mathrm{~min}$ ). Membranes were blocked with $5 \%$ milk for $1 \mathrm{~h}$ and washed three times with tris-buffered saline for 5 min each. Primary antibody (TH, DAT and $\alpha$-synuclein) diluted in $2 \%$ BSA was added to the membrane and incubated overnight at $4{ }^{\circ} \mathrm{C}$. The membrane was washed thrice with TBST for 5 min each. The secondary antibody diluted in $2 \%$ milk was then added to the membrane and incubated for a period of $1 \mathrm{~h}$ and washed with TBST. The bands were visualised with ECL solution [19].

\section{Data analysis}

Data were expressed as mean \pm SEM. The mean difference between the treatments was analysed by one-way ANOVA followed by Tukey's multiple comparisons as a posthoc test. $\$ 0.05$ is considered as significance criterion. Statistical analysis was performed using GraphPad Prism 5.0 version, USA.

\section{RESULTS}

The present study demonstrated the neuroprotective effect of Mimosa pudica against MPP+induced neurotoxicity in SHSY5Y cell lines.

\section{Standardisation of Mimosa pudica}

Basic phytochemical analysis revealed the presence of alkaloids, flavonoids, tannins and total phenols in the aqueous extract of Mimosa pudica. Flavonoids, tannins and total phenolic contents of Mimosa pudica were found to be $19.70 \pm 1.92,25.63 \pm 0.49$ and
$93.32 \pm 5.73$, respectively. Quercetin content in methanolic extract of Mimosa pudica was found to be $0.20 \pm 0.03 \% \mathrm{w} / \mathrm{w}$. Chromatogram of standard quercetin and Mimosa pudica were shown in fig. 2.

\section{Cell viability assay}

$\mathrm{IC}_{50}$ value of Mimosa pudica (concentration of extract required to cause 50\% cytotoxicity or cell death) was calculated from regression equation prepared from concentrations versus cytotoxicity. IC $\mathrm{I}_{50}$ value of Mimosa pudica was $211.05 \pm 3.65$ in the tested conditions (fig. 1A). The higher $\mathrm{IC}_{50}$ value indicates the non-toxic nature of Mimosa pudica to SHSY5Y cell lines.

\section{In vitro neuroprotective effects of Mimosa pudica}

In vehicle-treated cells, MPP+produced significant morphology changes like cell shrinkage, loss in membrane structure and loss in cell number (fig. 1B). Treatment with Mimosa pudica restored the cell structure and increased the cell viability by alleviating MPP+ induced neurotoxicity in SHSY5Y cell lines.

Treatment with $\mathrm{MPP}^{+}$significantly down-regulated the protein expression of TH $(\mathrm{F} \quad(3,8)=26.48), \mathrm{p}<0.01)$ and DAT $\quad(\mathrm{F}$ $(3,8)=13.35), p<0.01)$ when compared to vehicle treated cell lines. $\mathrm{MPP}^{+}$significantly up-regulated $\alpha$-syn (F $\left.(3,8)=10.80\right), \mathrm{p}<0.01$ ) expression when compared to vehicle treated cell lines. Treatment with Mimosa pudica significantly up regulated TH $(\mathrm{p}<0.01)$ and DAT $(\mathrm{p}<0.05)$ and down-regulated $\alpha$-synuclein $(\mathrm{p}<0.01)$ expression in $\mathrm{MPP}^{+}$intoxicated cell lines (fig. 3). These data reveal the neuroprotective potential of Mimosa pudica against MPP+ induced toxicity in SHSY5Y cell lines.

\section{DISCUSSION}

Parkinson's disease is a debilitating and progressive neurodegenerative condition, wherein till date the treatment strategies focus only on the symptomatic relief. Various classes of drugs such as dopamine agonist, dopamine replenishment therapy and monoamine oxidase inhibitors produce severe side effects and the sensitivity for the therapy goes low on long-term exposure. Yet, there is continuous efforts in the development of new drug therapies for the management of PD. Herbal based drugs offer substantial protective effects in the long-term management of various diseases including neurological disorders. Mimosa pudica was shown to have neuroprotective potential using various animal models of neurological disorders.

The mechanism of MPP+ induced neurotoxicity is largely mediated via mitochondrial dysfunction. MPP+ enters dopaminergic cells through dopamine transporter (DAT), and inhibits complex I in mitochondrial electron transport chain [8]. This decreases ATP production and triggers the generation of oxygen species (ROS) and apoptosis leading to neuronal death [9]. These data are consistent with the present study observation, wherein $\mathrm{MPP}^{+}$decreased DAT and TH expression, indicating dopaminergic neuronal death, which may be possible due to the accumulation of cytokines and oxidative stress. Mimosa pudica possesses wider pharmacological activities [10] and in particular, it is shown to exert neuroprotective activity such as anticonvulsant [11], anti-anxiety, anti-depression, adaptogenic and nootropic activities [12, 13]. These data demonstrated the neuronal reach of the active principles present in Mimosa pudica, in particular, tannins, flavonoids and total phenols. In the present study, Mimosa pudica was standardised for quercetin content which was found to be $0.20 \pm 0.03 \% \mathrm{w} / \mathrm{w}$ of aqueous extract. This is performed to ensure minimally or no batch to batch variation in the active principles present in Mimosa pudica keeping quercetin as a chemical marker. Quercetin was also shown to have antiParkinson's [14], anti-Alzheimer's [15], neuroprotective activity in cerebral ischemia and anti-neuro-inflammatory activity $[15,16]$.

Exposure to Mimosa pudica improved the TH and DAT expression and decreased $\alpha$-syn in the MPP+ intoxicated cell lines. This may be corroborated to protective effects against $\mathrm{MPP}^{+}$triggered free radical generation. Further, quercetin is also shown to possess substantial antioxidant activity [12]. Although at this stage, the mechanism of action of Mimosa pudica and active principles involved in the neuroprotective activity are not clear, in the present study, it 
(the anti-Parkinson's activity) may be due to quercetin which might act via the antioxidant mechanism. Our lab is involved in further studies to identify the active principles and to understand the mechanism of action of Mimosa pudica.

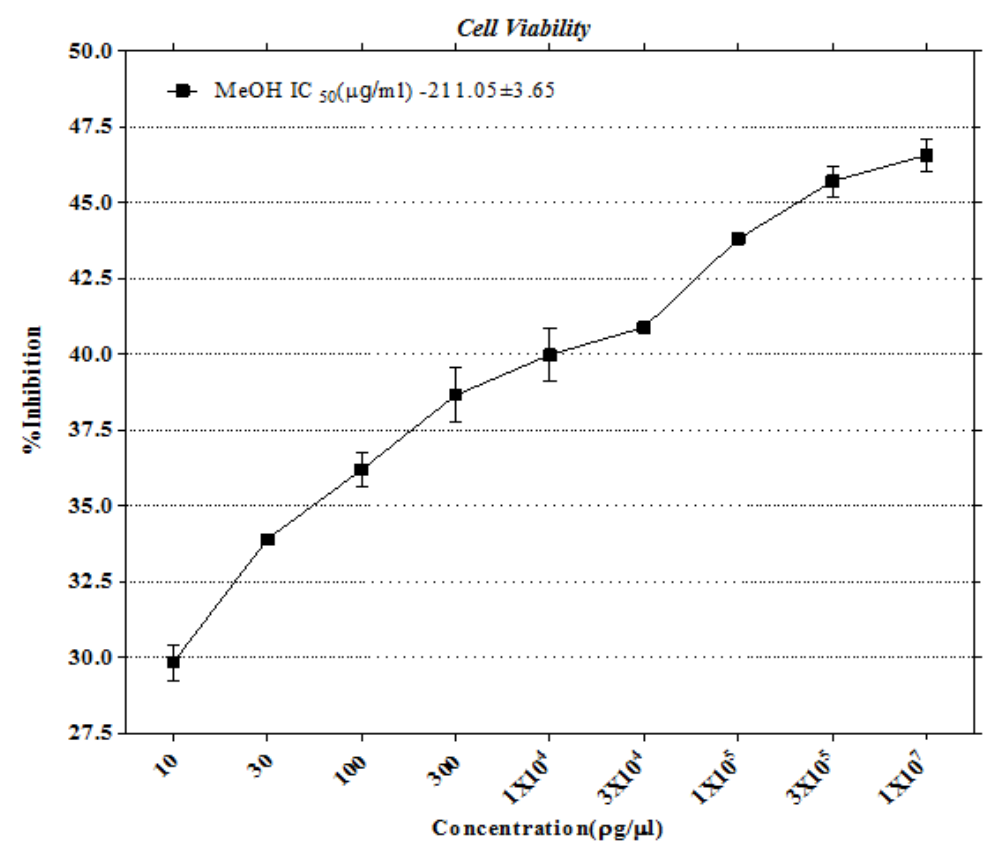

Fig. 1(A): \% inhibition of cell viability Mimosa pudica the values are expressed in pictogram

\section{Drug treatment}

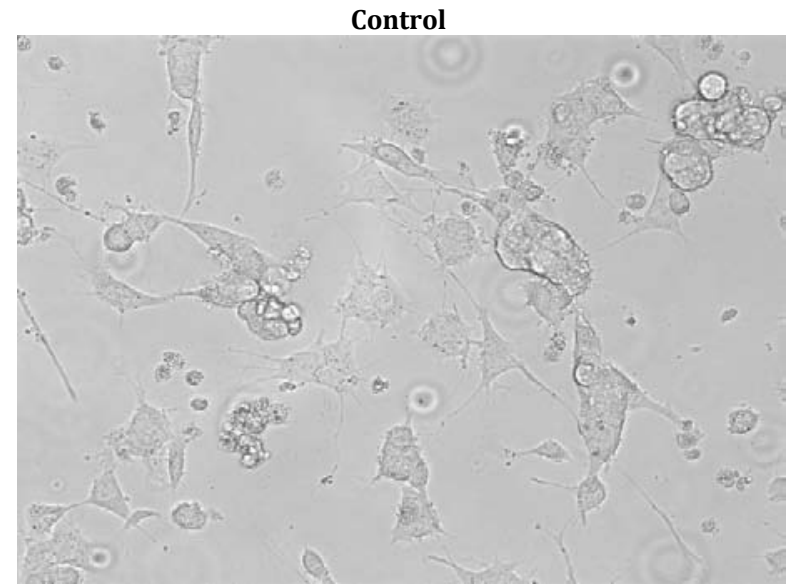

Mimosa pudica 100 mg+MPP+

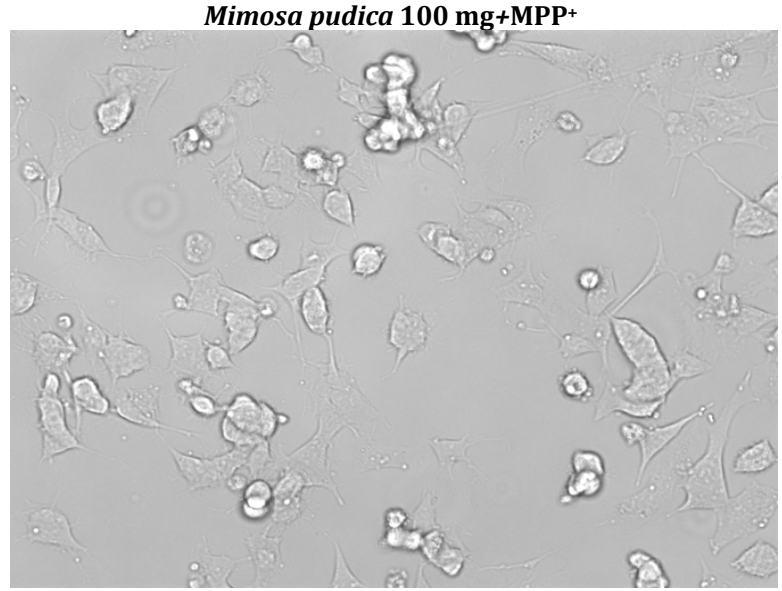

MPP+
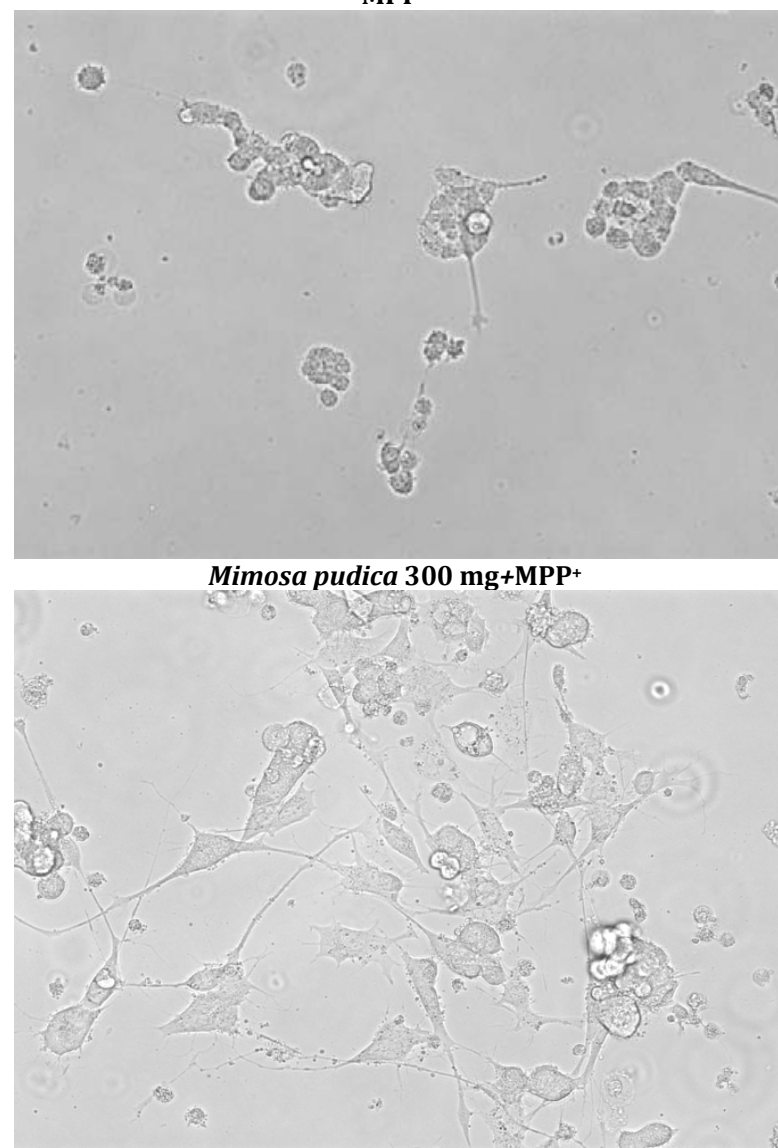

Fig. 1(B): Various Treatment of Mimosa pudica and MPP+. MPP+ treated cells shows cell shrinkage and Mimosa treated cells shows protection on neurons 

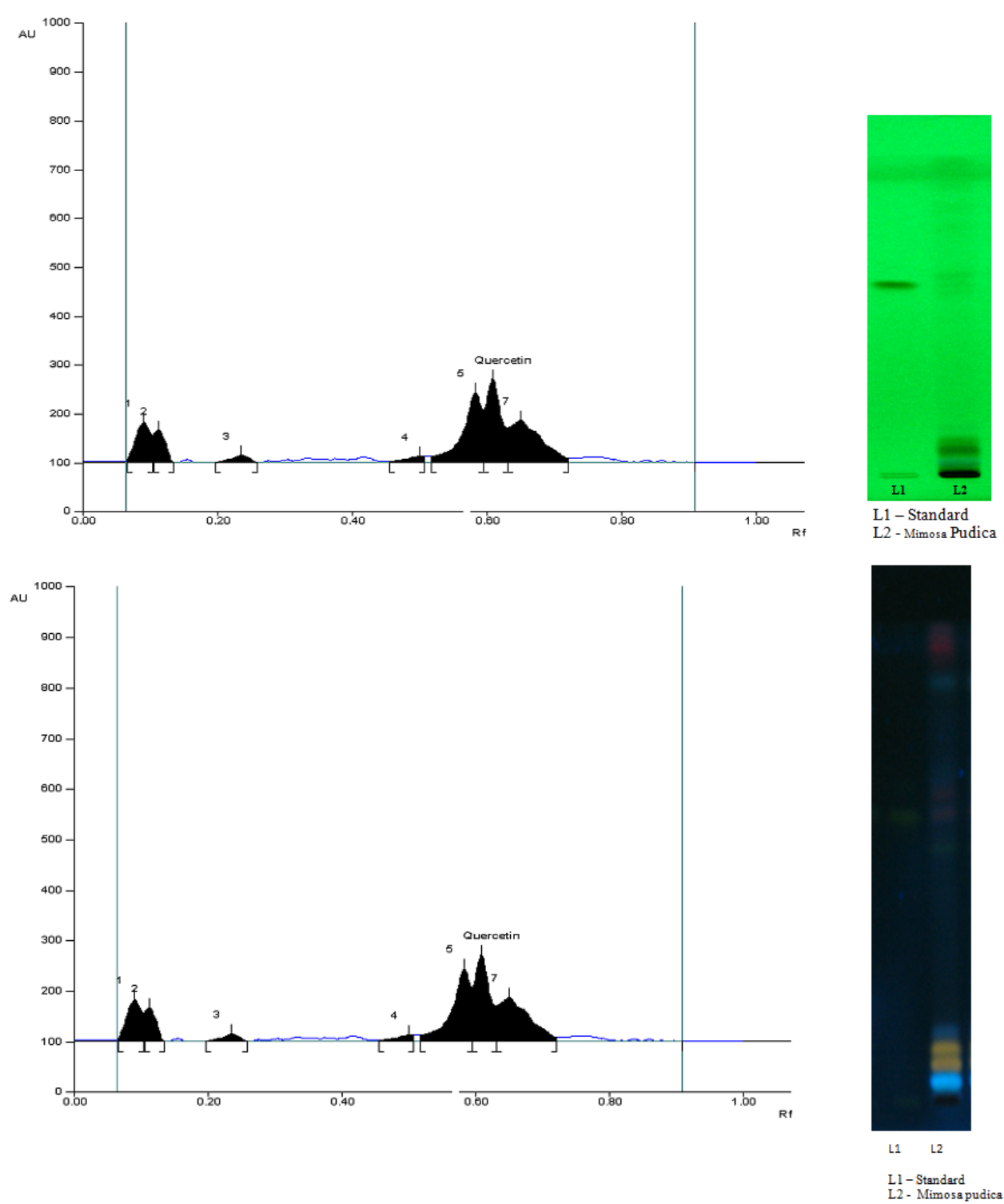

Fig. 2: Chromatogram shows Quercetin content of Mimosa pudica extract and standard quercetin

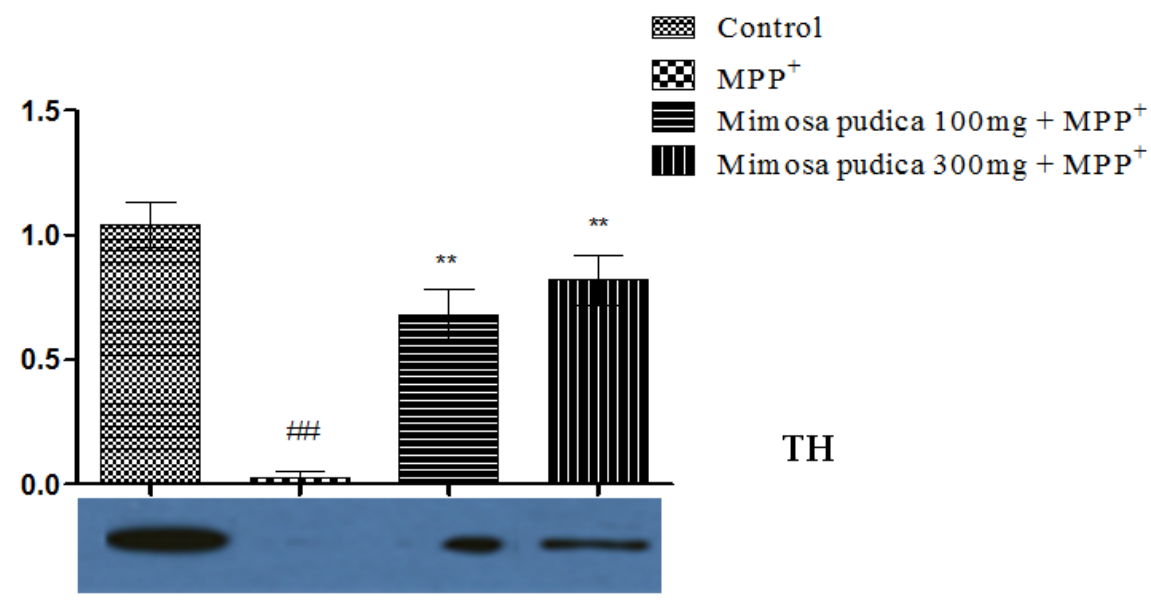

Fig. 3(A): Effect of Mimosa pudica on TH protein expression in MPP+ Treated cells. Values were expressed in mean \pm SEM. Statistical analysis was performed using one-way ANOVA followed by Tukey's multiple comparison tests; \#\# indicates p value $<0.01$ Vs group I, $* *$ indicates p value $<0.01$ Vs group II 


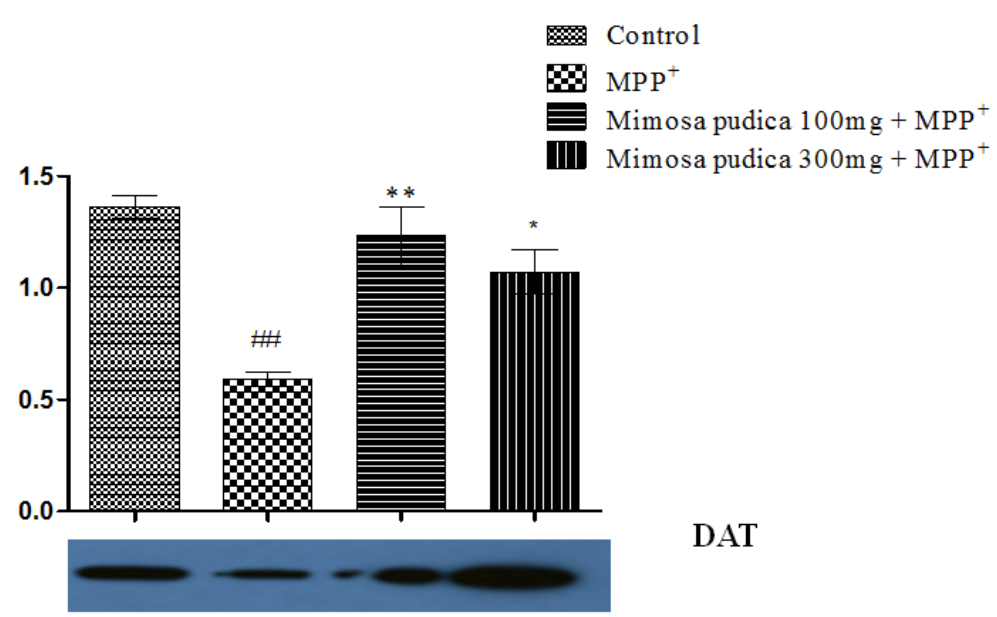

Fig. 3(B): Effect of Mimosa pudica on DAT protein expression in MPP+Treated cells. Values were expressed in mean \pm SEM. Statistical analysis was performed using one-way ANOVA followed by Tukey's multiple comparison tests, \#\# indicates p value $<0.01$ Vs group I, $*$,**indicates $p$ value $<0.05$ and 0.01 Vs group II

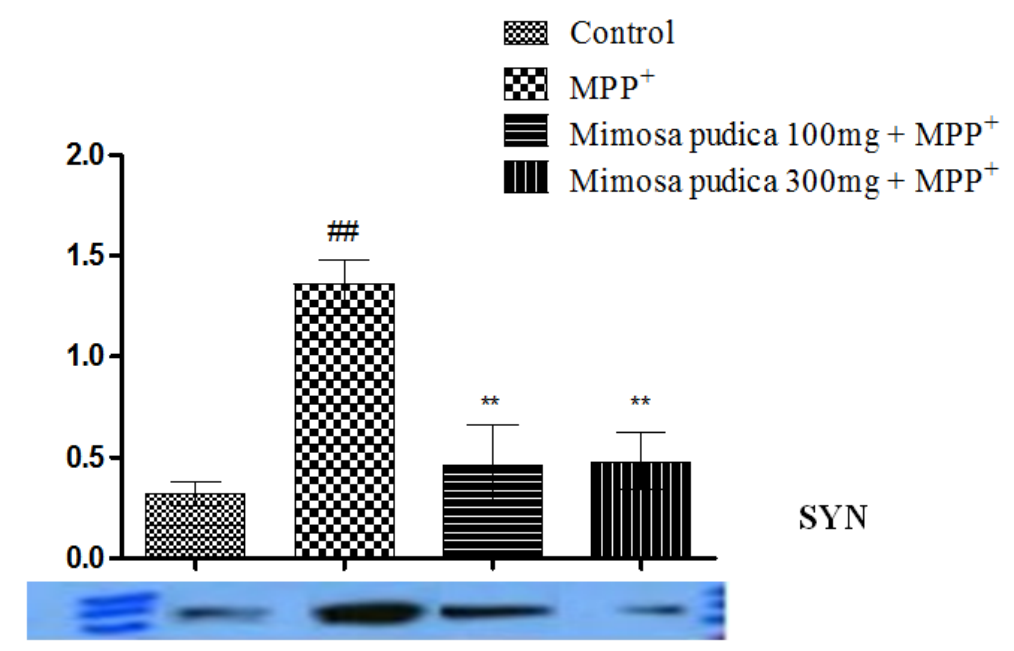

Fig. 3(C): Effect of Mimosa pudica on SYN protein expression in MPP+Treated cells. Values were expressed in mean \pm SEM. Statistical analysis was performed using one-way ANOVA followed by Tukey's multiple comparison tests; \#\# indicates p value $<0.01$ Vs group I, $* *$ indicates p value $<0.01$ Vs group II

\section{CONCLUSION}

Mimosa pudica possesses anti-Parkinson's activity, which may be corroborated by its antioxidant principles, at least partly due to quercetin.

\section{ACKNOWLEDGEMENT}

Authors thank Prof. Dr. M. Logamanian, Professor Emeritus, The Tamilnadu Dr. M. G. R. Medical University and Prof. Dr. P. Parthiban and Joint Director, Directorate of Indian medicine and Homoeopathy for their valuable advice during research. Authors thank Dr. N. J. Muthu kumar, Associate professor, HOD in-charge, Department Sirappu Maruthuvam. Authors thank Dr Saravana Babu, Asso. Prof, JSS College of Pharmacy, Mysuru, for his technical advice and support. Authors also thank Mr. Sugumar, Research Assitant, Madras Institute of Technology, for his help technical support and help in drafting the manuscript.

\section{ABBREVIATION}

PD-Parkinson's disease, ST-Striatum, SNpc-Substantia niagra pars compacta, SYN- $\alpha$-synuclein, TH-Tyrosine hydroxylase, DATDopamine transporter, TNF- $\alpha$-Tumor necrosis factor, IL- $1 \beta$ Interleukin $1 \beta$, MPP+-1-methyl-4-phenylpyridinium, HPTLC-High performance thin layer chromatography, DMEM-Dulbecco's modified eagles medium, IC ${ }_{50}$-Inhibitory concentration 50, DMSODimethyl sulfoxide, ECL-Enhanced chemiluminescence, SDS-Sodium dodecyl sulphate, SEM-Standard error of the mean.

\section{CONFLICT OF INTERESTS}

Authors declare no conflict of interest.

\section{REFERENCES}

1. Subbarayappa BV. Siddha medicine: an overview. Lancet 1997;350:1841-4.

2. Wang Q, Liu Y, Zhou J. Neuroinflammation in Parkinson's disease and its potential as a therapeutic target. Transl Neurodegener 2015;4:19.

3. Fellner L, Irschick R, Schanda K, Reindl M, Klimaschewski L, Poewe $\mathrm{W}$, et al. Toll-like receptor 4 is required for $\alpha$-synuclein dependent activation of microglia and astroglia. Glia 2013;61:349-60.

4. Kuppusamy KS. Uthamarayan. Siddha Vaithiya Thirattu 2014;5:268-9.

5. Kuppusamy KS. Siddha maruthuvam Inc. Indian Med Homeopathy 2012;8:584.

6. Murugesa Mudaliyar KS. Materia medica (Vegetable section), Inc. Indian Med Homeopathy 2013;1;551.

7. Zhang ZG, Wu L, Wang JL, Yang JD, Zhang J, Zhang J, et al. Astragaloside IV prevents $\mathrm{MPP}^{+}$-induced SH-SY5Y cell death via 
the inhibition of Bax-mediated pathways and ROS production. Mol Cell Biochem 2012;364:209-16.

8. Suzuki K, Mizuno Y, Yoshida M. Effects of 1-methyl-4-phenyl1,2,3,6-tetrahydropyridine (MPTP)-like compounds on mitochondrial respiration. Adv Neurol 1990;53:215-8.

9. Smeyne RJ, Jackson-Lewis V. The MPTP model of Parkinson's disease. Brain Res Mol Brain Res 2005;134:57-66.

10. Kshema J, Gopinathan N, Chitra K. Mimosa pudica Linn-A shyness princess: a review of its plant movement, active constituents, uses and pharmacological activity. Int J Pharm Sci Res 2014;5:5104-18.

11. Hafsa A, Sakshi S, Anurag M, Rajiv G. Mimosa pudica L. (Laajvanti): an overview. Pharmacogn Rev 2012;6:115-24.

12. Sibi PI, Delphia PG. Nootropic studies of ethanolic extract of Mimosa pudica Linn. in albino wistar rats. Am J Phytomed Clin Ther 2013;3:266-75.

13. Ganesh P, Subrat KB, Bijay KM. Effects of Mimosa pudica L. leaves extract on anxiety, depression and memory. Avicenna J Phytomed 2016;6:696-710.

14. Chuanfeng L, Hong T, Yang Z, Zhang Y, Wang L, Dong M, et al. Effect of quercetin in the 1-methyl-4-phenyl-1, 2, 3, a 6tetrahydropyridine-induced mouse model of Parkinson's disease. J Evidence-Based Complementary Altern Med 2012. http://dx.doi.org/10.1155/2012/928643

15. Suryakanta P, Abhisek P, Pratap KS. Neuroprotective effect of quercetin in neurotoxicity induced rats: the role of neuroinflammation in neurodegeneration. Asian J Pharm Clin Res 2014;7:152-6.

16. Sabogal-Guáqueta AM, Munoz-Manco JI, Ramirez-Pineda J, Lamprea-Rodriguez M, Osorio E, Cardona-Gomez GP. The flavonoid quercetin ameliorates Alzheimer's disease pathology and protects cognitive and emotional function in aged triple transgenic Alzheimer's disease model mice. Neuropharmacology 2015;93:134-45.

17. Siddha pharmacopoeia of India; 1973. p. 30-1.

18. Lakshmi N, Sasikumar M, Sunita S, Manisha B, Ramesh S. Reversed-phase high-performance thin-layer chromatographic quantification of mimosine from the whole plant of Mimosa pudica. Int J Pharm Chem 2007;20:49-51.

19. Wu CR, Tsai CW, Chang SW, Lin CY, Huang LC, Tsai CW. Carnosic acid protects against 6-hydroxydopamine-induced neurotoxicity in in vivo and in-vitro model of Parkinson's disease: involvement of antioxidative enzymes induction. Chem Biol Interact 2015;225:40-6.

\section{How to cite this article}

- Mahadevan MV, Ramaswamy RS, Banumathi V. Mimosa pudica exerts neuroprotection against MPP+Induced neurotoxicity in shsy5y cell lines an in vitro model of anti-parkinsonism. Int J Pharm Pharm Sci 2017;9(1):21-26. 